are recognised. Although the data are not available, it seems that the risk to the fetus of asymptomatic reinfection is small, ${ }^{31}$ and certainly it is far less than that of primary rubella. In the rare cases of symptomatic reinfection viraemia may be presumed to have occurred, putting the fetus at appreciable risk. ${ }^{9}$

An antibody response may be confidently ascribed to reinfection if two or more previous positive results for rubella antibody have been obtained. One previous positive result must be treated with scepticism as errors may have occurred. ${ }^{12}$ Hence the Royal College of Obstetricians and Gynaecologists and a working party of the Public Health Laboratory Service advise that every woman should be tested for rubella antibodies in every pregnancy. ${ }^{6} \mathrm{~A}$ history of rubella immunisation also means that primary rubella is unlikely, but vaccination failures are well recognised. ${ }^{12}$ If a patient has a rising titre of rubella antibody reinfection may be discriminated serologically from primary rubella if specific $\operatorname{Ig} M$ is not found or is found only in low concentration. ${ }^{31113}$ The recent finding of raised concentrations of specific IgM in confirmed reinfections (unpublished observations) adds to the problem. If only late serum samples are available and there is no history of previous testing or immunisation then specific $\operatorname{IgM}$ (even at low concentration) may reflect recent reinfection or primary rubella some weeks previously. Recently developed assays that measure specific IgG subclasses and avidity may allow this distinction to be made, but the tests have not yet been validated in routine use. ${ }^{1+16}$

A reliable and safe method of prenatal diagnosis of fetal infection would be valuable when there is diagnostic uncertainty or proved reinfection (although fetal infection does not necessarily mean fetal damage). Approaches include culturing amniotic fluid for rubella virus, which is time consuming and unreliable, and detecting specific $\operatorname{Ig} M$ in fetal blood, which has to be delayed until 23-24 weeks of pregnancy.
Detecting the rubella virus genome and antigen in chorionic villus samples is promising but requires further assessment. ${ }^{17}$

Correct diagnosis of primary rubella or reinfection in patients without symptoms may thus be difficult and lead to much anxiety about how to manage the pregnancy. It is thus essential for diagnosis that full information is given to the laboratory on symptoms, date and type of contact, previous rubella immunisation, and dates and results of previous tests for rubella antibody.

PETER MORGAN-CAPNER

Consultant Virologist,

Preston Infirmary,

Preston PR1 6PS

I Badenoch J. Big bang for vaccination. Br Med f 1988:297:750-1.

2 Miller E Cradock-Watson JE, Pollock TM Consequences of confirmed maternal rubella at successive stages of pregnancy. Lancet 1982;ii:781 4 .

Cradock-Watson JE, Ridehalgh MKS, Anderson MJ, Pattison JR. Outcome of astmptomatic infection with rubella virus during, Anderson MJ, Patison JR. Out:87:14-54.

Shirley JA, Revill S, Cohen BJ, Buckley MM. Serological study of rubella-like illnesses. f Med Virol 1987;21:369-79.

f.Med Tirol 1987;21:369-79.
Enders G, Knotek F. Detection of IgM antibodies against rubella virus: comparison of two indirect Enders $G$, Knotek F. Detection of $\operatorname{lgM}$ antibodies against rubella virus: comparist
ELISAs and an anti-IgM capture immunoassay. F Med Virol 1986;19:377-86.

6 Public Health Laboratory Service Working Party. Laboratory diagnosis of rubella. PHLS Microbiology Digest 1988;5:49-52.

Morgan-Capner P, Tedder RS, Mace JE. Rubella-specific IgM reactivity in sera from cases of infectious mononucleosis. Journal of Hygiene 1983;90:407-13.

$8 \mathrm{Kurtz} \mathrm{JB}$, Anderson MJ. Cross-reactions in rubella and parvovirus specific $\operatorname{IgM}$ tests. Lancet $1985 ;$;i: 1356

9 Morgan-Capner P. Does rubella reinfection matter? In: Mortimer PP, ed. Public health virologv. 12 Reports. London: Public Health Laboratory Service, 1986:50-62.

10 Hornstein L, Lery U, Fogel $\mathrm{A}$. Clinical rubella with virus transmission to the fetus in a pregnant woman considered to be immune. N Engl f.Med 1988:319:1415-6.

1 Morgan-Capner P. Hodgson J. Hambling $\mathrm{MH}$, et al. Detection of rubella-specific $\operatorname{lgM}$ in subclinical rubuli reinfection in pregnang. Lance 1985;:2446.

12 Miller CL, Miller E, Waighr PA. Rubella susceptibility and the continuing risk of infection in pregnancy. Br Med f 1987;294:1277-8.

13 Cradock-Watson JE, Ridehalgh MKS, Anderson MJ, Pattison JR. Rubella reinfection and the fetus. Lancet $1985 ; \mathrm{i}: 1039$.

14 Thomas HIJ, Morgan-Capner P. Specific IgG subclass antibody in rubella virus infections. Epidemiol Infect 1988;100:443-54

15 Rousseau S, Hedman K. Rubella infection and reinfection distinguished by avidity of IgG. Lancel 1988 ;i:1108-9.

16 Thomas HIJ, Morgan-Capner P. Rubella-specific IgG subclass avidity ELISA and its role in the differentiation between primary rubella and rubella reinfection. Epidemiol Infect 1988;101: 591-8.

17 Terry GM, Ho-Terry L, Warren RC, Rodeck CH, Cohen A, Rees KR. First trimester prenatal diagnosis of congenital rubella: a laboratory investigation. Br Med f 1986;292:930-3.

\title{
Inquiry into stillbirths and infant deaths
}

\section{We must have comparable regional surveys}

The government in its recent response to the report of the Social Services Committee on perinatal, neonatal, and infant mortality has accepted that because infant mortality is a key indicator of the nation's health the recent levelling off in its rate of decline represents a problem. ${ }^{1}$ It has rejected the committee's recommendations that funds should be earmarked centrally for allocation to areas of social deprivation and to those health authorities whose maternity and neonatal services are below standards outlined by the committee. It has also declined to prescribe the structure of neonatal intensive care services, reiterating its view that responsibility for the detailed planning and delivery of maternity and neonatal services must lie with regions and districts.

In some other respects, however, the government has responded positively to the committee's recommendations. It has agreed that improved understanding of why babies die must be an essential component of any strategy to reduce perinatal and later infant deaths. The government will consider the scope for further research and has already commissioned the Medical Research Council to undertake a review of the sudden infant death syndrome and advise on what new research is needed.

Informed assessment of the pathological causes of stillbirths and infant deaths is required, and this cannot happen without improved specialist pathology services. The NHS Management Executive has therefore been asked to ensure that all regions have at least one paediatric pathologist in post by 1991. Also endorsed is the committee's recommendation that procedures should be established for informing health authorities of the outcome of coroners' inquests.

These developments should improve the quality of the information provided by those who certify the causes of stillbirths and infant deaths and thus enhance the value of the vital statistics based on these certificates and published regularly by the Office of Population Censuses and Surveys. In addition, improved pathological investigation of stillbirths and infant deaths is needed for regionally based epidemiological surveys. Over the past decade there have been repeated calls for these developments, ${ }^{2-4}$ but only a minority of English regions have responded; the Northern region has the longest established survey ${ }^{5}$ and the only one now covering stillbirths and all infant deaths routinely. The government has now asked the NHS Management Executive to ensure that all regions have surveys in place by April 1991.

Regions should adopt the schemes for classifying and tabulating stillbirths and neonatal deaths which have been agreed and published jointly by representatives of the surveys in the Northern region and Scotland. ${ }^{6-8}$ For its part the 
government will have to make it clear that it intends to require NHS hospital trusts and private hospitals to provide data within the hospital episode system ${ }^{9}$ because these are required to generate denominators for the epidemiological surveys that regions are being required to set up. Regional epidemiological surveys are seen by the government to be not only invaluable for surveillance and a guide to where action is needed but also an essential precursor to introducing multidisciplinary confidential inquiry into particular categories of stillbirths and infant deaths. A working group is being set up by the chief medical officer to consider what form this might take.

In any inquiry process some categories of death - such as haemolytic disease, trauma, or respiratory distress in babies. weighing more than $1000 \mathrm{~g}$-might be studied as uncontrolled case series to assess whether care known to reduce the risk of death from these causes had been provided. Other categories - such as unexpected antepartum deaths of normally formed fetuses - would be more profitably investigated in case-control studies until more is understood about the underlying pathological processes and the means of successfully interrupting them. ${ }^{10}$ Those collaborating in the Northern region have already embarked on several such studies, and this would be a sensible place to pilot plans for any national confidential inquiry while other regions establish comparable surveys to ensure valid interregional comparisons and cross regional sampling of particular categories of death.

The government concludes the summary of its response to the Social Services Committee's report by expressing its belief that its initiatives will help to ensure that infant mortality becomes as low as possible. It does not refer to the possibility that striving for the highest possible rates of survival, while securing normal lives for many children who might otherwise have died, may also have tragic consequences for some other children. The rate of cerebral palsy among children who were born weighing less than $2500 \mathrm{~g}$ has risen in all of the populations for which data are available, ${ }^{11-14}$ and the overall rate of cerebral palsy in Sweden is now higher than at any time since records began. The government must accept that these and other children should be seen as the casualties of policies designed to ensure that infant mortality becomes as low as possible. It has an immediate duty to ensure that these children and their families receive the support they require to help them cope with the consequences of their disabilities. It has a further duty to ensure that the necessary data are available to monitor trends in cerebral palsy and other forms of impairment and to support the research required to identify ways of reducing the risk not only of infant death but also of serious impairment in children.

National Perinatal Epidemiology Unit, IAIN CHALMERS Director

Radcliffe Infirmary, Oxford OX2 6HE

1 Department of Health. Perinatal, neonatal and infant mortality: government reply to the first report of the Social Services Committee, session 1988-89. London: HMSO, 1989. (Cmnd 741.)

2 Chalmers I, Mcllwaine G, eds. Perinatal audit and surveillance. London: Royal College of Obstetricians and Gynaecologists, 1980.

3 Chalmers I. Enquiry into perinatal death. Br f Obstet Gynaecol 1985;92:545-9.

4 Barron SL. How can we improve perinatal surveillance? Br f Obstet Gynaecol 1986;93:1201-3.

5 Northern Regional Health Authority Coordinating Group. Perinatal mortality: a continuin collaborative regional survey. Br Med f 1984;288:1717-20.

6 Cole SK, Hey EN, Thomson AM. Classifying perinatal death: an obstetric approach. Br f Obstet Gynaecol 1986;93:1204-12.

7 Hey EN, Lloyd DJ, Wigglesworth JS. Classifying perinatal death: fetal and neonatal factors. Brf Obstet Gynaecol 1986;93:1213-23.

8 Macfarlane $\mathrm{A}$, Cole $\mathrm{S}$, Hey E. Comparisons of data from regional perinatal mortality surveys. Brf Obstet Gynaecol 1986;93:1224-32.

9 Freeman R. Parliamentary written answer. House of Commons Official Report (Hansard) 1989 March 6;148:col 415. (No 63.)

10 Chalmers I. Enquiry into perinatal death: a report on national perinatal surveillance prepared for the Department of Health and Social Security. Oxford: National Perinatal Epidemiology Unit, 1984.

11 Hagberg B, Hagberg G, Olow I, von Wendt L. The changing panorama of cerebral palsy in Sweden. V. The birth year period 1979-82. Acta Paediatr Scand 1989;78:283-90.

12 Dowding V, Barry C. Cerebral palsy: changing patterns of birthweight and gestational age 1976/81). Ir Med f 1988;81:25-9.

13 Pharaoh POD, Cooke T, Rosenbloom I, Cooke RWI. Trends in the birth prevalence of cerebral palsy. Arch Dis Child 1987;62:379-89.

14 Stanley FJ, Watson L. The cerebral palsies in Western Australia: trends, 1968 to 1981. Am $\mathcal{J}$ Obstet Gynecol 1988;158:89-93.

\section{Radiology about to go digital}

\section{Exciting new technology must be carefully evaluated}

Computed tomography, radionuclide scanning, digital subtraction angiography, and magnetic resonance imaging account for up to one third of examinations in modern radiology departments: they yield digital data, giving measurements of physical values from which images are constructed. At present these images are printed on film. The technology now exists to transform other examinations into digital procedures. Computed radiography is a Japanese innovation that replaces $x$ ray film with a reusable phosphor material. ${ }^{12}$ After exposure with conventional radiographic equipment the phosphor sheet is removed from its cassette and scanned to convert the stored image into digital data. The system is more sensitive than film, and more tolerant of incorrect exposure; the procedure entails less radiation and, theoretically, no chemicals and no film.

Linking imaging technology in a computerised network that would allow radiologists and doctors in clinics and operating theatres to deal exclusively with digital images on television systems has long been a pipe dream. ${ }^{3+}$ In the early days, however, few people fully appreciated the true scale of the undertaking. The London Stock Exchange now generates 350 megabytes of data from each day's trading; a fully digital radiology department in a typical hospital might easily produce 2 gigabytes - nearly six times more.

Single full sized optical disks are inadequate for storing such huge amounts of image data. Optical jukeboxes have been devised to handle 90 or more disks, and there is now the prospect of optical tape that might store a terabyte of data (1 million megabytes) on a single reel. In a hospital with a fully digital radiology system thousands of images from hundreds of patients would need to be instantly available for viewing in dozens of locations. This would give rise to enormous problems with data traffic. Laying down standards and finding ways for existing and future equipment-even from a single manufacturer - to communicate in the same language is difficult and costly. The many technical problems have been studied intensively, mostly in the United States. ${ }^{56}$ The work has been largely conducted by psychiatrists, computer scientists, and engineers.

As solutions appear for technical problems formidable pressure to implement the new technology becomes inevitable - rather like the pressure to introduce a wonder drug that is not yet available for clinical use. This is of special concern to hospitals that are rebuilding or planning for the future and have to consider the prospects for installing a complete network. They need to exercise caution and restraint. There is a sharp contrast between the missionary zeal of those who are frustrated with film but have had no practical experience with the new systems and the realism of established research teams. 